\title{
Evaluation of Different Doses of Fungicides and Biocides against Spot Blotch of Wheat Caused by Bipolaris sorokiniana
}

\author{
Sunil Kumar ${ }^{1}$, Prem Naresh ${ }^{1}$, Virendra Kumar ${ }^{2 *}$, Ramesh Singh $^{1}$ and S.K. Biswas ${ }^{1}$ \\ ${ }^{1}$ Department of Plant Pathology, C.S Azad University of Agriculture and Technology, \\ Kanpur-208002, India \\ ${ }^{2}$ Swami Vivekanand University Sagar (M.P.) 470003, India \\ *Corresponding author
}

\section{A B S T R A C T}

Keywords

Spot blotch,

Fungicide,

Biocides, Bipolaris sorokiniana, Poison food method and Wheat

\section{Article Info}

Accepted:

10 November 2018

Available Online:

10 December 2018
Wheat (Triticum estivum L.) is the major and important winter cereal food crop grown in India during Rabi season. The crop suffer from a number of devastating disease by fungi, bacteria, virus, phytoplasmas, nematodes and many other factors which educe yield and quality. The major fungal disease of wheat, spot blotch caused by Bipolaris sorokiniana is the most devastating disease in India and several other countries. The diseases affect all areal part of the plant.. Many new fungicides and biocides have been under taken to evaluate with poison food method. Out of nine fugicides in different concentrations of seven fungicides and two biocides (Neemexel and $T$. viride) have been revealed that the dose no. $4^{\text {th }}\left(\mathrm{D}_{4}\right)$ have given best result to reducing mycelial growth of Bipolaris sorokiniana comparison to others. It has also found that the growth of fungus was fast up to first four days and after that it is gradually reduced. In some concentrations like, $0.12 \%$, $0.25 \%$ growth of mycelia was stringent after fifth days of inoculation. The maximum inhibitory effect with $73.33 \%$ reduction was recorded at $0.25 \%$ concentration of Nativo 75 WG fungicides which was statistically at per with $0.12 \%$ concentration. It was followed by $0.06 \%$ concentration with $68.88 \%$ reduction was recorded with Raxil 060 FS.

\section{Introduction}

Wheat (Triticum estivum L.) is the major and important winter cereal food crop grown in India during Rabi season. It contributes major part to the food security system and provides more than 50 per cent calories to the people those are mostly dependent on wheat as a staple food (Sahai Suman, 2009). India occupies the second place in term of production and area, among the major wheat growing countries of the world after china. But in India, Uttar Pradesh have rank first both in area and production of wheat amongst the different major wheat growing states viz. Punjab, Haryana, Delhi, Rajasthan and M.P. of country and hold $1 / 3$ share in the countries out of the total wheat area and production. However in the background of increasing population, the demand for wheat is increasing day by day, but production and productivity in India are remained stringent for last few 
decades which solely contributed due to some biotic and abiotic factors likes' insect, disease, weeds and nutritional deficiency constraints, in which one of the most important reason is disease.

Wheat crop suffers from several diseases which reduce yield and quality. The crop suffer from a number of devastating disease by fungi, bacteria, virus, phytoplasmas, nematodes and many other factors (Joshi et $a l .$, 1986). The major fungal disease of wheat, spot blotch caused by Bipolaris sorokiniana is the most devastating disease in India and several other countries. The diseases affect all areal part of the plant. The disease adversely affect wheat yield particularly under late sown condition due to the practice of most popular rice - wheat cropping system. The yield losses due to spot blotch disease may vary from variety to varieties and region to region. Nema and Joshi (1971) the pathogen main problem reported 3-20\% loss under different agroclimatic condition. The management of disease can be done through cultural, chemical, biological and use of resistant variety.

The cultivation of wheat with resistant verity is cheap and best method but resistant variety may be converted in to the susceptible are due to development of resistant strains among created to this method. Cultural practices (sanitation, crop rotation and summer ploughing) prevented the development to spot blotch disease in the field condition but method fail where it has already appeared in the standing crop. Biological control is easy and cheap method but bio agent having varying growth even slow growth and unfit for the adverse weather condition (Singh, 2003). Hence application of chemical is one of the most effective and widely recommended methods of disease management. Continues use of same chemical may develop resistant strain of pathogen therefore, there is need to change of chemical at a frequent interval of time. Hence many new fungicides and biocides have been under taken to evaluate with poison food method in the present investigation.

\section{Materials and Methods}

\section{Isolation of Bipolaris sorokiniana}

Naturally infected wheat leaf was collected from Student's Experimental Research Farm of C.S.A. Uni. Agri. \& Tech., Kanpur. The disease portion of leaves were cut into $2 \mathrm{~mm}$. long pieces by sterilized blade and washed 3-4 times with sterilized water in order to remove the dust and other contamination. These pieces were dipped in $0.1 \% \mathrm{HgCl}_{2}$ for about $20-30$ second then washed thoroughly in 3-4 times to remove the remaining trace of $\mathrm{HgCl}_{2}$. The pieces were then transferred with the help of sterilized needle in sterilized Petri-dishes containing $2 \%$ PDA medium previously poured aseptically and were incubated in BOD at $25 \pm 1^{0} \mathrm{C}$. The pure culture was established by hyphal tip isolation method (Rangaswami, 2008). Fungus was identified by comprising its morphological character with old identified culture of Bipolaris sorokiniana and authentic description as given by Ellis (1971). The stock culture of Bipolaris sorokiniana were revived after every fort night and maintained through on PDA in sealed culture tubes at $5^{\circ} \mathrm{C}$ in refrigerator.

\section{Collection of fungicide and biocide}

The fungicides like Raxil 060FS, Trifloxystrobin 500SC, Trifloxystrobin + Tebeconazole 080 FS, Vitavax, Flint (Trifloxystrobin) $50 \quad$ WG, Nativo (Trifloxystrobin 25\% + Tebeconazole 50\%) $75 \mathrm{WG}$ and Tebeconazole 2\% DS were provided by Bayer crop Science Limited Mumbai and Hydrabad. 
Bioagent like Sanjeevini commercial formulation of Trichoderma viride was collected from Department of Plant Pathology C. S. Azad University of Agriculture and Technology, Kanpur for the present investigation.

Neem based commercial formulation Neemexcel was also collected from local market at Rawatpur, Kanpur.

\section{Preparation of bioagent solution}

Seven days old culture was used to prepare homogenous suspension of bio agent. The suspension containing conidia and mycelium bit was churned in a warning blender and strained with cheese cloth. The suspension containing of approximately 103-105 conidia was used for this study.

\section{Solution preparation of fungicides}

To study the effect of the different fungicides and biocides on spore germination and growth of pathogen the fungicides viz. Raxil $060 \mathrm{FS}$, Trifloxystrobin 500 SC, Trifloxystrobin + Tebeconazole 080 FS, Vitavax, Flint (Trifloxystrobin) $50 \quad$ WG, Nativo (Trifloxystrobin $25 \%+$ Tebeconazole $50 \%$ ) 75 WG and Tebeconazole 2\% DS and biocides like Sanjeevini and Neemexcel of different doses were tested in laboratory.

Raxil 060 FS, Trifloxystrobin 500 SC, Tebeconazole $2 \%$ DS, Trifloxystrobin + Tebeconazole 080 FS, Nativo (Trifloxystrobin $25 \%$ + Tebeconazole 50\%) 75WG, Flint (Trifloxystrobin) 75 WG likes are new fungicides and there is need to standardize it concentrations. Therefore exactly $0.03 \mathrm{mg}$, $0.06 \mathrm{mg}, 0.12 \mathrm{mg}$ and $0.25 \mathrm{mg}$ of six fungicides, were weighted and dissolved in water separately in $100 \mathrm{ml}$ of water to prepare $0.03,0.06,0.12$ and, $0.25 \%$ concentrations of fungicides.
Effect of doses of fungicides and biocides on mycelial growth of Bipolaris sorokiniana (Food Poison Method)

The experiment was conducted by poison food technique as describe by Schmitz (1930).The six fungicides and their four doses to prepare $0.03,0.06,0.12$ and, $0.25 \%$ concentrations of fungicides, $0.03 \mathrm{mg}, 0.06 \mathrm{mg}, 0.12 \mathrm{mg}$ and $0.25 \mathrm{mg}$, were weighted and dissolved in PDA separately in $100 \mathrm{ml}$ of PDA in $250 \mathrm{ml}$ flask. The medium containing fungicide was mixed thoroughly and poured in Petri plate and allow solidifying. Each treatment was replicated three times. One Petri plate contain only medium without any fungicide to serve as a control. Discs of ( $0.5 \mathrm{~cm}$ diameter), mycelial bit was cut by the cork borer and placed at the centre of Petri plate and then Petri-plates were incubated at incubated at $28 \quad \pm 1^{0} \mathrm{C}$. Observation on the mycelial growth of fungi in each Petri plate was recovered at every 24 hrs up to seven days of incubation. One Petriplate contain only medium without any fungicide and biocide serve as a control.

\section{Results and Discussion}

Effect of doses of fungicides and biocides on mycelial growth of Bipolaris sorokiniana (Food Poison Method)

The effect of different concentrations of fungicides and biocides on suppression of mycelial growth of $B$. sorokiniana was recorded after every 24 hour up to 7 days of inoculation.

It was evident from the (Table 1) that suppression of mycelial growth of $B$. sorokiniana began after five days of inoculation. It has also found that the growth of fungus was fast up to first four days and after that it is gradually reduced. In some concentrations like, $0.12 \%, 0.25 \%$ growth of mycelia was stringent after fifth days of inoculation. 
Int.J.Curr.Microbiol.App.Sci (2018) 7(12): 988-993

Table.1 Effect of different concentration fungicides and biocides on mycelial growth of $B$. sorokiniana (Food Poison Method)

\begin{tabular}{|c|c|c|c|c|c|c|c|c|c|c|c|}
\hline \multirow[t]{2}{*}{ S. No. } & \multirow[t]{2}{*}{ Fungicide } & \multirow[t]{2}{*}{ Dose } & \multicolumn{7}{|c|}{$\begin{array}{l}\text { Mycelium growth of Biopoloris sorokiniana } \\
\text { (Diameter in } \mathrm{Cm} \text { ) 1-7 days }\end{array}$} & \multirow[t]{2}{*}{ Mean } & \multirow[t]{2}{*}{$\begin{array}{l}\text { Reduction in } \\
\text { growth \% }\end{array}$} \\
\hline & & & 1 & 2 & 3 & 4 & 5 & 6 & 7 & & \\
\hline \multirow[t]{8}{*}{1.} & Raxil 060 FS & $\mathrm{D}_{1}$ & 0.5 & 1.2 & 2.5 & 4.0 & 4.1 & 4.2 & 5.2 & 3.10 & 43.33 \\
\hline & & $\mathrm{D}_{2}$ & 0.5 & 1.2 & 2.5 & 3.8 & 4.1 & 4.1 & 5.2 & 3.06 & 42.22 \\
\hline & & $\mathrm{D}_{3}$ & 0.5 & 1.2 & 2.0 & 2.5 & 2.6 & 2.6 & 2.6 & 2.00 & 71.11 \\
\hline & & $\mathrm{D}_{4}$ & 0.5 & 1.0 & 2.3 & 2.9 & 2.5 & 2.5 & 2.5 & 2.02 & 72.22 \\
\hline & & $\mathrm{D}_{5}$ & 0.5 & 2.5 & 4.4 & 5.8 & 7.0 & 8.1 & 9.0 & 6.32 & 0.00 \\
\hline & Mean & & 0.50 & 1.45 & 2.74 & 3.80 & 4.06 & 4.30 & 4.90 & & \\
\hline & & & & & $\mathbf{A}$ & & B & & & $\mathbf{A} \times \mathbf{B}$ & \\
\hline & C.D. at $5 \%(\mathrm{P}=0.05)$ & & & & 0.21 & & 0.25 & & & 0.55 & \\
\hline \multirow[t]{8}{*}{2.} & $\begin{array}{l}\text { Trifloxystrobin } 500 \\
\text { SC }\end{array}$ & $\mathrm{D}_{1}$ & 0.5 & 1.2 & 2.4 & 3.8 & 4.0 & 4.2 & 4.2 & 2.90 & 53.33 \\
\hline & & $\mathrm{D}_{2}$ & 0.5 & 1.2 & 2.0 & 3.2 & 3.8 & 4.2 & 4.2 & 2.72 & 53.33 \\
\hline & & $D_{3}$ & 0.5 & 1.0 & 1.4 & 1.8 & 2.4 & 2.8 & 2.8 & 1.81 & 68.88 \\
\hline & & $\mathrm{D}_{4}$ & 0.5 & 1.0 & 1.2 & 1.5 & 2.0 & 2.4 & 2.8 & 1.62 & 68.88 \\
\hline & & $\mathrm{D}_{5}$ & 0.5 & 2.5 & 4.4 & 5.8 & 7.0 & 8.1 & 9.0 & 5.32 & 0.00 \\
\hline & Mean & & 0.5 & 1.38 & 2.29 & 3.22 & 3.84 & 4.34 & 4.60 & & \\
\hline & & & & & A & & B & & $\mathbf{A} \times \mathbf{B}$ & & \\
\hline & C.D. at $5 \%(\mathrm{P}=0.05)$ & & & & 0.21 & & 0.25 & & 0.55 & & \\
\hline \multirow[t]{8}{*}{3.} & $\begin{array}{c}\text { Trifloxystrobin+ } \\
\text { Tebuconazole } 080 \mathrm{FS}\end{array}$ & $\mathrm{D}_{1}$ & 0.5 & 1.2 & 2.5 & 4.1 & 4.2 & 4.2 & 4.2 & 2.96 & 53.33 \\
\hline & & $\mathrm{D}_{2}$ & 0.5 & 1.2 & 2.5 & 3.8 & 4.1 & 4.1 & 4.2 & 2.90 & 53.33 \\
\hline & & $D_{3}$ & 0.5 & 1.5 & 2.0 & 2.1 & 2.3 & 2.5 & 2.5 & 1.90 & 72.22 \\
\hline & & $\mathrm{D}_{4}$ & 0.5 & 1.0 & 1.8 & 2.0 & 2.5 & 2.5 & 2.5 & 1.82 & 72.22 \\
\hline & & $\mathrm{D}_{5}$ & 0.5 & 2.5 & 4.4 & 5.8 & 7.0 & 8.1 & 9.0 & 5.30 & 0.00 \\
\hline & Mean & & 0.50 & 1.48 & 2.64 & 3.60 & 4.02 & 4.30 & 4.50 & & \\
\hline & & & & A & & B & & $\mathbf{A} \times \mathbf{B}$ & & & \\
\hline & C.D. at $5 \%(\mathrm{P}=0.05)$ & & & 0.31 & & 0.37 & & 0.83 & & & \\
\hline \multirow[t]{8}{*}{4.} & Vitavax & $\mathrm{D}_{1}$ & 0.5 & 1.2 & 2.4 & 4.1 & 4.1 & 4.2 & 4.2 & 2.95 & 53.33 \\
\hline & & $\mathrm{D}_{2}$ & 0.5 & 1.2 & 2.1 & 2.6 & 3.0 & 3.4 & 4.1 & 2.40 & 54.44 \\
\hline & & $\mathrm{D}_{3}$ & 0.5 & 1.0 & 2.3 & 2.5 & 2.5 & 2.5 & 2.5 & 1.97 & 72.22 \\
\hline & & $\mathrm{D}_{4}$ & 0.5 & 1.0 & 2.5 & 2.5 & 2.5 & 9.5 & 2.5 & 2.00 & 72.22 \\
\hline & & $\mathrm{D}_{5}$ & 0.5 & 2.5 & 4.4 & 5.2 & 7.0 & 8.1 & 9.0 & 5.24 & 0.00 \\
\hline & Mean & & 0.50 & 0.40 & 2.74 & 3.40 & 3.80 & 4.14 & 4.46 & & \\
\hline & & & & A & & B & & $\mathbf{A} \times \mathbf{B}$ & & & \\
\hline & C.D. at $5 \%(\mathrm{P}=0.05)$ & & & 0.10 & & 0.12 & & 0.28 & & & \\
\hline \multirow[t]{3}{*}{5.} & $\begin{array}{l}\text { Flint (trifloxystrobin) } \\
50 \mathrm{WG}\end{array}$ & $\mathrm{D}_{1}$ & 0.5 & 1.2 & 2.4 & 4.0 & 4.1 & 4.2 & 4.2 & 2.94 & 53.33 \\
\hline & & $\mathrm{D}_{2}$ & 0.5 & 1.2 & 2.0 & 2.8 & 4.0 & 4.1 & 4.2 & 2.68 & 53.33 \\
\hline & & $D_{3}$ & 0.5 & 1.0 & 1.5 & 2.0 & 3.2 & 3.2 & 3.2 & 2.08 & 64.44 \\
\hline
\end{tabular}


Int.J.Curr.Microbiol.App.Sci (2018) 7(12): 988-993

\begin{tabular}{|c|c|c|c|c|c|c|c|c|c|c|c|}
\hline & & $\mathrm{D}_{4}$ & 0.5 & 1.0 & 1.5 & 1.8 & 3.0 & 3.0 & 3.0 & 1.97 & 66.66 \\
\hline & & $\mathrm{D}_{5}$ & 0.5 & 2.5 & 4.4 & 5.8 & 7.0 & 8.1 & 9.0 & 5.32 & 0.00 \\
\hline & Mean & & 0.50 & 1.38 & 2.36 & 3.28 & 4.26 & 4.52 & 4.72 & & \\
\hline & & & & A & & B & & $\mathrm{A} \times \mathrm{B}$ & & & \\
\hline & C.D. at $5 \%(\mathrm{P}=0.05)$ & & & 0.15 & & 0.18 & & 0.42 & & & \\
\hline \multirow[t]{8}{*}{6.} & $\begin{array}{c}\text { Nativo } \\
\text { (Triofloxystribin 25\% } \\
+ \text { Tebuconazole 50\%) } \\
75 \text { WG }\end{array}$ & $\mathrm{D}_{1}$ & 0.5 & 1.2 & 1.8 & 2.8 & 3.5 & 4.6 & 5.8 & 2.88 & 35.55 \\
\hline & & $\mathrm{D}_{2}$ & 0.5 & 1.2 & 1.8 & 2.5 & 2.8 & 2.8 & 2.8 & 2.05 & 68.88 \\
\hline & & $\mathrm{D}_{3}$ & 0.5 & 1.2 & 1.8 & 2.6 & 2.8 & 2.8 & 2.8 & 2.07 & 68.88 \\
\hline & & $\mathrm{D}_{4}$ & 0.5 & 1.2 & 1.8 & 2.4 & 2.4 & 2.4 & 2.4 & 1.87 & 73.33 \\
\hline & & $\mathrm{D}_{5}$ & 0.5 & 2.5 & 4.3 & 5.6 & 7.2 & 7.5 & 9.0 & 5.22 & 0.00 \\
\hline & Mean & & 0.50 & 1.50 & 2.30 & 3.20 & 3.74 & 4.02 & 4.56 & & \\
\hline & & & & & A & & B & & $\mathrm{A} \times \mathrm{B}$ & & \\
\hline & C.D. at $5 \%(\mathrm{P}=0.05)$ & & & & 0.10 & & 0.12 & & 0.28 & & \\
\hline \multirow[t]{8}{*}{7.} & Trichoderma viride & $\mathrm{D}_{1}$ & 0.5 & 1.2 & 2.2 & 4.0 & 4.1 & 4.2 & 4.2 & 2.91 & 53.33 \\
\hline & & $\mathrm{D}_{2}$ & 0.5 & 1.2 & 1.8 & 2.6 & 3.2 & 4.2 & 4.2 & 2.53 & 53.33 \\
\hline & & $\mathrm{D}_{3}$ & 0.5 & 1.2 & 1.5 & 2.2 & 2.4 & 2.8 & 2.8 & 1.91 & 68.88 \\
\hline & & $\mathrm{D}_{4}$ & 0.5 & 1.0 & 1.4 & 2.0 & 2.4 & 2.8 & 2.8 & 1.84 & 68.66 \\
\hline & & $\mathrm{D}_{5}$ & 0.5 & 2.5 & 4.4 & 5.8 & 7.0 & 8.1 & 9.0 & 5.32 & 0.00 \\
\hline & Mean & & 0.50 & 1.42 & 2.26 & 3.32 & 3.82 & 4.42 & 4.60 & & \\
\hline & & & & A & & B & & $\mathrm{A} \times \mathrm{B}$ & & & \\
\hline & C.D. at $5 \%(\mathrm{P}=0.05)$ & & & 0.15 & & 0.17 & & 0.39 & & & \\
\hline \multirow[t]{8}{*}{8.} & Neemexcel & $\mathrm{D}_{1}$ & 0.5 & 1.2 & 2.2 & 4.0 & 4.1 & 4.2 & 4.2 & 2.91 & 53.33 \\
\hline & & $\mathrm{D}_{2}$ & 0.5 & 1.2 & 2.0 & 3.2 & 3.8 & 4.2 & 4.2 & 2.72 & 53.33 \\
\hline & & $\mathrm{D}_{3}$ & 0.5 & 1.0 & 1.8 & 2.4 & 2.4 & 2.8 & 2.8 & 1.95 & 68.88 \\
\hline & & $\mathrm{D}_{4}$ & 0.5 & 1.0 & 1.4 & 2.0 & 2.4 & 2.8 & 2.8 & 1.84 & 68.88 \\
\hline & & $\mathrm{D}_{5}$ & 0.5 & 2.5 & 4.4 & 5.8 & 7.0 & 8.1 & 9.0 & 5.32 & 0.00 \\
\hline & Mean & & 0.50 & 1.38 & 2.36 & 3.84 & 3.94 & 4.42 & 4.60 & & \\
\hline & & & & A & & B & & $\mathrm{A} \times \mathrm{B}$ & & & \\
\hline & C.D. at $5 \%(\mathrm{P}=0.05)$ & & & 0.23 & & 0.27 & & 0.62 & & & \\
\hline \multirow[t]{8}{*}{9.} & Tebuconazole 2\% DS & $\mathrm{D}_{1}$ & 0.5 & 1.2 & 2.2 & 4.0 & 4.1 & 4.2 & 4.2 & 2.91 & 53.33 \\
\hline & & $\mathrm{D}_{2}$ & 0.5 & 1.2 & 2.0 & 3.2 & 3.8 & 4.2 & 4.2 & 2.72 & 53.33 \\
\hline & & $\mathrm{D}_{3}$ & 0.5 & 1.0 & 1.8 & 2.4 & 2.8 & 3.2 & 3.2 & 2.12 & 64.44 \\
\hline & & $\mathrm{D}_{4}$ & 0.5 & 0.5 & 1.0 & 1.8 & 2.2 & 2.8 & 2.8 & 1.65 & 68.88 \\
\hline & & $\mathrm{D}_{5}$ & 0.5 & 2.5 & 4.4 & 5.8 & 7.0 & 8.1 & 9.0 & 5.32 & 0.00 \\
\hline & Mean & & 0.50 & 1.28 & 2.29 & 3.44 & 3.99 & 4.50 & 4.68 & & \\
\hline & & & & A & & B & & $\mathrm{A} \times \mathrm{B}$ & & & \\
\hline & C.D. at 5\% (P=0.05) & & & 0.31 & & 0.37 & & 0.82 & & & \\
\hline
\end{tabular}

Where- $\mathrm{D}_{1}=0.33 \mathrm{ml} /$ lit., $\mathrm{D}_{2}=0.66 \mathrm{ml} /$ lit., $\mathrm{D}_{3}=1.25 \mathrm{ml} /$ lit., $\mathrm{D}_{4}=2.50 \mathrm{ml} /$ lit., $\mathrm{D}_{5}=$ Control.

$\mathrm{A}=\mathrm{It}$ indicate dose level. $\mathrm{B}=\mathrm{It}$ indicate number of days 
The maximum inhibitory effect with $73.33 \%$ reduction was recorded at $0.25 \%$ concentration of Nativo 75 WG fungicides which was statistically at par with $0.12 \%$ concentration. It was followed by $0.06 \%$ concentration with $68.88 \%$ reduction was recorded with Raxil 060 FS.

Viswanathan and Narayanaswamy (1992) found that Tricyclazole and Mancozeb at the different concentrations effectively inhibited the spore germination and mycelial growth of D.oryzae.

Biswas et al., (2008) also reported that seed treatment with biocides such as Trichoderma harzianum and $T$. viride and so on were tested against $D$. orzae and Rhizoctonia solani and found that biocides provide good protection of seed against seed borne infection, resulting in enhanced germination and shoot and root length of paddy seeds.

Naresh et al., (2009) also evaluated that out of out of ten fungicides 4 viz. zineb, thiram, TPTA and ziram were found most effective against mycilial growth of $B$. sorokiniana.

Out of six treatments (i.e. Tebuconazole, Tetraconazole, Trifloxystrobin + propiconazole, Azoxystrobin + cyproconazole, Trifloxystrobin + cyproconozole and control) including control, the better response found in Tebuconazole and Tetraconazole to effective inhibition on the mycelium growth of Bipolaris maydis Yamashita et al., (2010).

\section{References}

Biswas, S.K., Ved Ratan, Sriwastava, S.S.L. and Singh Ramesh(2008). Influence of seed treatment with biocides and foliar spray with fungicides for management of brown leaf spot and sheath blight of paddy. Indian Phytopathology, 61:1, 5559.

Ellis, M.B. (1971). Dematiaceaous hypomycetes, C.M.I., Kew, Surry, England, 608 pp.

Rangaswami, G. (2008). Diseases of crop plant in India. PHI Learning Pvt. Ltd, New Delhi. pp165.

Schmitz, H.(1930). A suggested toximetrics methods for food preservation. Indust. Ind. English chem. Analyst Ed., 4:361363.

Joshi L.M., Gera, S.D., Adlakha, K.L. and Sriwastava, K.D. (1986). In problems and progress of wheat pathology in South Asia. Malhotra Publising, New Delhi, 404pp.

Nema, K.G., and Joshi, L.M. (1971). The spot blotch disease of wheat caused by Helmithosporium sativum. Proc. Second Int. Symp. Plant Path., I.A.R.I., New Delhi. Pp. 42.

Sahai, Suman (2009). Acknowledge the farmer as a cultivator, conserver and seed producer: The Hindu Survey of Indian Agriculture. Pp.135.

Naresh Prem, S.K. Biswas, Upesh Kumar and Mohd. Rajik (2009). Effect of media, pH, temperature, host range and fungicides on Bipolaris sorokiniana. Ann.pl. Protec. Sci., 17(2): 394-397.

Singh, Chhidda (2003). Modern techniques of field crops raising. pp 46-58. Oxford and IBH Co. Ltd., New Delhi.

Yamashita, O.M., Kobasti, L., CassetariNeto D., Santi, A. Peres, W.M. Carvalho, M.A.C., Kappes C.(2010). In vitro effect of fungicides on mycilial growth of Bipolaris maydis. Scientia Agaria Paranaensis, 9(1): 37-44.

\section{How to cite this article:}

Sunil Kumar, Prem Naresh, Virendra Kumar, Ramesh Singh and Biswas, S.K. 2018. Evaluation of Different Doses of Fungicides and Biocides against Spot Blotch of Wheat Caused by Bipolaris sorokiniana. Int.J.Curr.Microbiol.App.Sci. 7(12): 988-993.

doi: https://doi.org/10.20546/ijcmas.2018.712.122 